\title{
Knowledge and Use of Medicinal Traditional Plant Species Ailments in Haramaya, Ethiopia
}

\author{
Melaku Masresha Woldeamanuel \\ Department of Chemistry, Dire Dawa University, Dire Dawa, Ethiopia \\ Email address: \\ sofon2ms@gmail.com
}

\section{To cite this article:}

Melaku Masresha Woldeamanuel. Knowledge and Use of Medicinal Traditional Plant Species Ailments in Haramaya, Ethiopia. International Journal of Environmental Chemistry. Vol. 3, No. 1, 2019, pp. 18-23. doi: 10.11648/j.ijec.20190301.13

Received: February 14, 2019; Accepted: March 25, 2019; Published: May 11, 2019

\begin{abstract}
The purpose of this research was to identify the medicinal plants and anal-yse local knowledge regarding the use of plants for the treatment and prevention of various human ailments in socio-cultural groups, namely in the peoples of Haramaya, East Harerge, Ethiopia by answering research questions: What were the requirements of the users in filling existing gap in knowledge regarding the traditional medicinal plants? What are the traditional medicinal plants species used as a primary healthcare? Which parts of traditional medicinal plants are used as a primary health care? How does the medicinal plant products are operated by healers? Data was selected from Haramaya District, HarargeZone, East Ethiopia from September 2016 to July 2017thedata were collected from 30 randomly selected traditional plant healer's using semi-structured interviews and participants observation. The traditional plant species healers were involved in the study were male and female and also their ages range from 25 -95. Interviews were made with each traditional healer about the knowledge and use of medicinal plant species used to treat human diseases in the study area. 22 medicinal plant species were used as cure for 30 ailments. From these, 100 species were recorded for the treatment of human health problems, from the total medicinal Plants. The most frequently used plant parts were leaves (31\%), seeds (27\%), seeds and fruits (3.5\%) fruits $(3.5 \%)$, steam (10.35\%), roots $(6.7 \%)$, jelly of the steam $(3.5 \%)$, flowers $(3.5 \%)$, leave bud $(3.5 \%)$, leaves and roots $(3.5 \%)$ and terminal bud $(3.5 \%)$. The most widely used method of preparation was crushing $(26.80 \%)$ of the different plant parts followed by squeezing $(22.68 \%)$ and burning $(7.21 \%)$. The common route of administration recorded was oral (52.01\%) followed by dermal (28.52\%) and nasal $(8.3 \%)$. The most commonly used application of medicinal plant was drinking (43.37\%) followed by painting $(10.84 \%)$ and put on and washing accounted for $10.84 \%$. No significant correlation was observed between the age of traditional remedy and the number of species reported and the indigenous knowledge transfer was found to be similar. More than one medicinal plants species were used more frequently than the use of a single species for remedy preparation. Plant parts used for remedy preparations showed significant difference with medicinal plant species abundance in the study area.
\end{abstract}

Keywords: Medicinal Plants, Plant Parts, Traditional Healers

\section{Introduction}

Brief History of Traditional Medicine in Ethiopia

The first recorded epidemic that occurred in Ethiopia dates back to 849 following the expulsion of Abba Yohannes, the head of the Ethiopian church, from the land. The plague and famine that ensued was perceived as God's punishment for Yohannes' misdeeds. In a terrified letter to Abba Yohannes, the Ethiopian emperor wrote that "great tribulations have come upon our land, and all our men are dying of the plague and all of our beasts and cattle have perished" [1].

The Biofarm Project, Addis Ababa, Ethiopia; Copyright:
WHO/P. Virot It is impossible to pinpoint the birth of medicine in Ethiopia, but certainly the evolution of curative practices closely follows the path of a disease. Traditional medical practitioners mostly implement herbs, spiritual healing, bone-setting and minor surgical procedures in treating disease. Ethiopian traditional medicine is vastly complex and diverse and varies greatly among different ethnic groups. Most traditional medical practices in Ethiopia rely on an explanation of disease that draws on both the "mystical" and "natural" causes of an illness and employ a holistic approach to treatment [2].

Under the rule of Menelik (1865-1913) Western medicine 
became significantly more incorporated into the Ethiopian medical system. Numerous medical envoys from abroad, starting with the Italians and Russians, were influential in building hospitals, providing medical training and participating in vaccination campaigns. However, most medical establishments primarily served the urban elites and foreign missionaries and were concentrated in the major cities [1].

Despite Western medicine becoming more widespread in Ethiopia, Ethiopians tend to rely more on traditional medicine. Conventional medical services remain concentrated in urban areas and have failed to keep pace with the growing population, keeping health care access out of reach for most Ethiopians living in Ethiopia. Because traditional medicine is culturally entrenched, accessible, and affordable, up to $80 \%$ of the Ethiopian population relies on traditional remedies as a primary source of health care [3]. Moreover, Western medicine has become more focused on preventative measures and people seeking curative practices still rely on indigenous medicine as the primary source for health care [1]. The influence of traditional medicine is also seen in Ethiopian migrant populations. In countries with substantial Ethiopian immigrant populations, traditional herbs, medical devices, and practitioners are readily available [4].

Popular knowledge of plants used by humans is based on thousands of year's experience. By "trial and error", people learnt how to recognize and use plants, including those with a magic-religious function. Among the oldest testimonies to plant use were the pollen remains of medicinal plants found on an archaeological dig at Shanidar (Iraq). These were about 60,000 years old, from the Neanderthal period Knowledge of plant use was widespread in ancient civilizations. Until the middle of the 19th century, plants were the main therapeutic agents used by humans, and even today their role in medicine is still relevant [5].

The term ethnobotany was coined in 1895 by the North American botanist John Harshberger to describe studies of "plants used by primitive and aboriginal people" [6]. By the end of the 19th century ethnobotany had started to develop as a science, providing a new tool for pharmaceutical research. Public institutions, such as the World Health Organization, and private pharmaceutical companies started to invest funds in ethnobotanical expeditions to tropical regions (mainly in America and Africa), to gather in-digenous knowledge of medicinal plants and collect samples for laboratory investigation [7].

Medicinal plant resources in Africa are also the major source of income. In addition to domestic trade, medicinal plants are widely exported in large volumes to the international market. The continent comes second to Asia in export figures [8]. The Ethiopian Flora is estimated to consist of between six and seven thousand species distributed in about 245 plant families. Although the exact number is still unknown, a large number of the species, i.e., about one-third of the families, have been employed in traditional medicinal practices [9].
In Ethiopia, even though the traditional medical practitioners are the best sources of information about the knowledge of the medicinal plants, it was found very difficult to obtain their traditional medicinal information as they considered their indigenous knowledge as a professional secret, only to be passed orally to their older son, at their oldest age [10]. However, the local indigenous knowledge on medicinal plants is being lost at a faster rate with the increase of modern education, which has made the younger generation to underestimate its traditional values.

In addition the increase in population growth rate would result in the intensification of agriculture in marginal areas which would lead to deforestation with decrease in number or loss of medicinal plants in the wild [11-12]. Estimated that $95 \%$ of traditional medical preparations in Ethiopia are of plant origin. Medicinal plants are the base for the development of new drug and the survival of till human kind as well as other livestock. In Ethiopia little emphases has been given to traditional medicinal studies over the past decade [3].

There for it can be said that ethno botanical studies are merely at the start in Ethiopia through there have been some attempts in investigating medicinal plants uses and there is as yet no in depth study on the relation between medicinal plants and indigenous knowledge on sustainable management of such plant resources. Modern healthcare has never been and probably never will provide for the foreseeable future adequate and equitable health service anywhere in Africa, due to the financial limitations related to rapid population growth, political instability and poor economic performance [14].

In the context of medicinal plant which probably grow to more scientific and a fully acceptable manner, locally used and acceptable plants and its product must be differentiated. Before used event in the era of scientific and technology medicinal plants has great role in the causing different medicinal disease, although the mode of action and dosages are not exactly understand.

Medicinal plants are those plants available in a given environment:

1 Used to treat disease of specific origin but not specific causative agent. These plants are not found anywhere uniformly and it is geographic and agro-ecologic dependent.

2 In this research report, one must recognized and understand the value of medicinal plants. Its uses, types, which medicinal plants and to care which type of disease and the geographic distributions of the plants.

3 So the research may partially, answer the questions raised by different individually students during academic and practical session of the study of biology and related subject matters. It also tries to clarify the value of altitudes of learners and the community toward medicinal plants and survives way for further detailed research on the topic in such a way that the for coming student uses it as a reference material.

It is known that any person in this world no one can be 
free of any medicinal problems. This must be elicited oneself not to be easily vulnerable to medicinal problems (diseases). That is as it said for any action there is reaction. Communities find prompt solution for any medicinal problems (diseases), they face. When communities act on their medicinal problems (diseases) besides scientifically fabricated medicines, they make use of medicinal plants for their treatment. Therefore, it is significant to conduct research on various aspect traditional medicinal plants, since it is widely used in the communities

Among rural communities in Haramaya, as would be the case elsewhere, traditional Medication is believed to be an important healthcare system, which mainly involves the use of locally available medicinal plants. Recently, some studies were done on some localities of Ethiopia [13, 15-23]. Nevertheless, no study was done to include medicinal plants and indigenous knowledge of the local communities of Haramayain the medicinal records of Ethiopia. This study is believed to add up to the country database of medicinal plants and in documenting local knowledge of the people. This study has been initiated to conduct ethno botanical study of medicinal plants in Haramaya and to compile and document indigenous plant based medical knowledge of the people.

The general objective of this research is to identify the medicinal plants and anal-yse local knowledge regarding the use of plants for the treatment and prevention of various human ailments in socio-cultural groups, namely the peoples of Haramaya, East Harerge, and Ethiopia, respectively. With the following

Specific objective: collect and document plant species used to treat human ailments in the study area, grouping certain medicinal plants according to their functionality, identify factors threatening medicinal plants in the study area, identifying the negative attitudes toward traditional medicinal plants and provide information by answering the following research questions: What were the requirements of the users in filling existing gap in knowledge regarding the traditional medicinal plants? What are the traditional medicinal plants species used as a primary healthcare? Which parts of traditional medicinal plants are used as a primary health care? How does the medicinal plant products are operated by healers?

\section{Methodology}

\subsection{The Study Area}

The study was conducted at Haramaya, East Ethiopia from September 2016 to June 2017. Haramaya is one of the woredas in the Oromia Region of Ethiopia. Haramaya is bordered on the south by kurfachile, on the west by kersa, on the north by Dire Dawa, on the east by kombolcha, and on the southeast by Harari Region. The altitude of this woreda ranges from 1400 to 2340 meter above sea level: the higest point include Dof and Jeldo. The major river is theAmaresa;bodies of water including lake Haramaya. The socio economic activities of local population is depend up on farming cash crop khat, vegetable and fruits are important cash crops the wereda is the major vegetable producer for Djibouti.

\subsection{Sample and Sampling Techniques}

In the Haramaya, East Ethiopia has about 500 house holders. From this randomly 30 house holders are selected for this study. Then also from the 30 population which randomly interviewed 10 are the healers of traditional medicinal plants. The questions which interviewed for the population and healers selected are analyzed as contextually i.e. two questions are $100 \%$ of them are returned for the researcher from the population and healers after they respond the interviewed questions and the others 3 question are analyzed what they answers.

\subsection{Data Collection}

An ethno medicinal plant species study data was selected from Haramaya District, Hararge Zone, East Ethiopia from September 2016 to July 2017. Ethno medicinal plants data were collected from 30 randomly selected traditional plant healer's using semi-structured interviews and participants observation. The traditional plant species healers were involved in the study were male and female and also their ages range from $25-95$, the study illiterate able to read and write, while few of them are an able to write and read.

Interviews were made with each traditional healer about the knowledge and use of medicinal plant species used to treat human diseases in the study area. The healers were like professionals they practices who medicate the local people by using ethno medicinal plants and their products. The interviews were facilitated the local language of the people (Afan Oromo).

Verbal informed consent was obtained from each individual traditional medicinal plant species healer who was participating during the field period. Voucher samples of each traditional medicinal plant species were also collected during the field visit and allotted collection numbers

\subsection{Data Analysis}

The data which was collected from Haramaya District, East Harargezone, East Ethiopiafor medicinal traditional plant species where analyzed after collecting the entire questionnaire and interviews in percentage with table in order to indicate the number of respondents out of the total population and healer's sampled.

\section{Results}

Within the study area medicinal traditional plant species ingredients of traditional remedy and they were considered as main primary health care and frequently where the first choice. They were treating resource poor people who had little access and couldn't afford the cost for modern medication. They also reported that the local people have 
been seeking for their treatment in the connection with the communities believe that they would not get better medication for some of the diseases in modern health services. The medicinal traditional plant species in the study area indicated that they served the community best as distribution of health services.

Generally, from the data collected the results of medicinal traditional plant species in the study areas were:

$122 / 3$ family name of plants (botanical families) were used to treat diseases are (mentioned)

230 medicinal traditional plant species are described by the scientific name.

3 Plant parts used and methods of preparation to treat ailments in the study were prescribed in therapies.

420 human diseases (ailments) were identified by the traditional remedy of the study.

For more understanding medicinal traditional plant species in the study area see table 1 lists of medicinal traditional plant local name (Afan Oromo), botanic name (family name), and scientific name parts used methods of preparation and diseases treats.

Data on human element treated study were local name of plants used, family name, scientific name, parts used, methods of preparation and diseases treated recorded according to the below lists of samples

Table 1. Lists of the medicinal traditional plant species of the study sample.

\begin{tabular}{|c|c|c|c|c|c|c|}
\hline S.N & $\begin{array}{l}\text { Local Name of } \\
\text { plants in afanoromo }\end{array}$ & $\begin{array}{l}\text { Botanical family } \\
\text { name }\end{array}$ & Scientific Name & Part(s) Used & $\begin{array}{l}\text { Preparation and/or } \\
\text { administration processes }\end{array}$ & Troubles treated \\
\hline 1 & Makkanniisa & Euphorbiaceae & Croton macrosta & Terminal bud & $\begin{array}{l}\text { Applying terminal bud over skin } \\
\text { infection (roobbii) }\end{array}$ & Fungi of the skin \\
\hline 2 & Shonkoora & Poaceaeaceae & Saccharumofficinarum & Stems & Hotting parts of stem \& eating & Common cold \\
\hline 3 & Sunqoo & Fabaceae & Tringonellafoenum & Seeds & $\begin{array}{l}\text { Seedling \& drying then powdering } \\
\text { soluble drink. }\end{array}$ & Gastric infection \\
\hline 4 & Talbba & Linaceae & Linumusitatissinum & Seeds & Soluble \& drink & Gastric infection \\
\hline 5 & Asaangira & Solanaceae & Daturastramonium & Leaves & $\begin{array}{l}\text { Crushing leaves \& applying over } \\
\text { head }\end{array}$ & Wound of head \\
\hline 6 & Dhummuugaa & Loranthaceae & Oliverellahildebranth & Leaves & $\begin{array}{l}\text { Hotting the leaves \&applying over } \\
\text { the infection of skin }\end{array}$ & Cold \\
\hline 7 & Qobboo & Euphobiaceae & Ricinuscommunisl & Leaves & $\begin{array}{l}\text { Hotting the leaves \&applying over } \\
\text { the infection of skin }\end{array}$ & Cold \\
\hline 8 & Yeroo & Lamiaceae & Pycnostachsabyssinica & Leaves & $\begin{array}{l}\text { Hotting the leaves \&applying over } \\
\text { the infection of skin }\end{array}$ & Eye infection \\
\hline 9 & Qabarichoo & Asteraceae & Echinopshispidus & Roots & $\begin{array}{l}\text { Infusion/streaming the root of } \\
\text { plant }\end{array}$ & Evil (michii) \\
\hline 10 & Xeenaddama & Rutaceae & Rutagraveolensl & Leaves \& root & $\begin{array}{l}\text {-Drinking leaves with tea/coffee } \\
\text {-Pounding the root then drinking }\end{array}$ & $\begin{array}{l}\text {-common cold } \\
\text {-garaaciniinnaaf }\end{array}$ \\
\hline 11 & Caatii & Celastraceae & Catha edulis & Leaves bud & $\begin{array}{l}\text { Drinking the leaves bud with } \\
\text { tea/coffee }\end{array}$ & Tonsil \\
\hline 12 & Buna & Rubiaceae & Coffeaarabiaca & Seeds & $\begin{array}{l}\text {-Powdering \& drinking } \\
\text {-Applying the powder over wound }\end{array}$ & $\begin{array}{l}\text {-headache } \\
\text {-wound }\end{array}$ \\
\hline 13 & $\begin{array}{l}\text { Yaatuu } \\
\text { (daraarkeelloo) }\end{array}$ & Asteraceae & Acmellacausirhizadal & Flowers & Chewing the yellow flowers & Tonsil \\
\hline 14 & Harkisa (maxxannee) & Boraginaceae & Cynolossumlaceolatum & $\begin{array}{l}\text { Jelly of the } \\
\text { stems }\end{array}$ & $\begin{array}{l}\text { Jelly of the stem apply over the fire } \\
\text { wounds }\end{array}$ & Fire wounds \\
\hline 15 & ArangamaaGurraacha & Apocynaceae & Carissa spinarum & Roots & $\begin{array}{l}\text { Hotting the roots \& applying over } \\
\text { the illness teeth }\end{array}$ & Tooth decay \\
\hline 16 & Qorxobbii & Plantaginaceae & Plantagolaceolata & Seeds & $\begin{array}{l}\text { Powdering the seeds then applying } \\
\text { the blooding bodies }\end{array}$ & Blooding bodies \\
\hline 17 & Zinjibila & Zinjiberaceae & Zingiberofficinale & Stems & $\begin{array}{l}\text { Crushing \& eating/drinking with } \\
\text { nutrient/tea }\end{array}$ & $\begin{array}{l}\text { Common cold, } \\
\text { tonsil, relieve } \\
\text { nausea }\end{array}$ \\
\hline 18 & Qullubbiiadii & Alliaceae & Allium sativum & Stems & $\begin{array}{l}\text { Peeling the cover then eat with } \\
\text { nutrient }\end{array}$ & $\begin{array}{l}\text { Common cold, } \\
\text { malaria } \\
\text { (antibiotic \& } \\
\text { cardio vascular) }\end{array}$ \\
\hline 19 & Qullubbiidiimaa & Alliaceae & Allium cepal & leaves & Eating parts of leaves & Common cold \\
\hline 20 & Gurraattii & Ranunculaceae & Nigella sativa & Seeds & Chewing seeds & Common cold \\
\hline 21 & Paappayyaa & Caricaceae & Caica papaya & Seeds \& fruits & Applying fire wounds & Fire wound \\
\hline 22 & Loomii & Cucurbitaceae & Citrus aurantifolia & Fruits & Applying over skin & Skin infection \\
\hline 23 & Baargamooadii & Myrtaceae & Eucalyptua globules & Leaves & Chewing leaves & $\begin{array}{l}\text { Common cold } \\
\text { Influenza }\end{array}$ \\
\hline 24 & Sinaafica & Amaranthaceae & Spinaciaoleraceal & Seeds & Powdering \& eating & $\begin{array}{l}\text { Gastro intestinal } \\
\text { ailments }\end{array}$ \\
\hline 25 & Raafuu & Baceaerassic & Brassica carinatel & Leaves & Cooking leaves \& eating & Gastric infection \\
\hline 26 & Ijagoommanaa & Brassicaceae & Brassica carinatel & Seeds & Saamitawaliinmooquun & $\begin{array}{l}\text { Miidhamaaf } \\
\text { Dubartiideesseef }\end{array}$ \\
\hline
\end{tabular}




\begin{tabular}{lllllll}
\hline S.N & $\begin{array}{l}\text { Local Name of } \\
\text { plants in afanoromo }\end{array}$ & $\begin{array}{l}\text { Botanical family } \\
\text { name }\end{array}$ & Scientific Name & Part(s) Used & $\begin{array}{l}\text { Preparation and/or } \\
\text { administration processes }\end{array}$ & Troubles treated \\
\hline 27 & Eebicha & Asteraceae & Vernoniaamygdalina & Leeves & Brushing enamel of teeth & $\begin{array}{l}\text { Removing } \\
\text { bacteria from the } \\
\text { teeth }\end{array}$ \\
28 & Shinfaa & & Seeds & $\begin{array}{l}\text { Powdering seeds \& eating with } \\
\text { food }\end{array}$ & Worms of flarie \\
29 & Geeshoo & & leaves & Chewing leaves & tonsil \\
\hline
\end{tabular}

Table 2. Responses on the use of medicinal traditional plant species in percent.

\begin{tabular}{lllll}
\hline Item & Number of population that randomly interviewed & Percent (\%) & Number of 10 healer's & Percent (\%) \\
\hline Yes & 30 & 100 & 10 & 100 \\
No & - & - & - & - \\
Total & 30 & 100 & 10 & 100 \\
\hline
\end{tabular}

This table shows that $100 \%$ of population and healers that areas have the knowledge and use of medicinal traditional plant species.

Table 3. Responses on the plant part used for medicinal plant remedy in percent.

\begin{tabular}{lllll}
\hline Parts of plants used & Number of population that randomly interviewed & Percent (\%) & Number of 10 healer's & Percent (\%) \\
\hline Root & 30 & 100 & 10 & 100 \\
Flower & 30 & 100 & 10 & 100 \\
Seed & 30 & 100 & 10 & 100 \\
Leaf & 30 & 100 & 10 & 100 \\
\hline
\end{tabular}

This table indicates that $100 \%$ of population and healers interviewers are responds on the parts of plant roots, flowers, seeds, and leaves used for medication.

The response for question "in your area how did you use (methods of preparation) to use this medicinal traditional plant species?" are":

(1) By chewing parts that plants used for medicate

(2) By crushing, squeezing and powdering of the various parts of medicinal plant species for medication

(3) By applying over skin, eating and drinking with necessary soluble admissive like sugar, honey, tea, coffee, edible, oil, etc were you used in the remedy preparation.

The response for the question "the knowledge and use of medicinal traditional plant species to disease treated of their local area?" and their answers are:

To treat from common cold (to relieve nausea), tonsils, headache, fire wounds (treating wounds), tooth decay, bleeding bodies, malaria (antibiotic and cardio vascular disease), skin infection, influenza, gastric worms(gastro intestinal ailments), gastric, removing bacteria from the teeth, coughs and sore throat, worms of flarie, miidhamaaf, etc.

The response for the question "how did you take care and route administration of medicinal traditional plant species?" in your environments are:

Among they mentioned medicinal traditional plant species of the study area were majority are cultivated, where as some of the reported medicinal traditional plant species were both cultivated and wild, also few species were indicated as wild.

The management of traditional therapies knowledge and empirically are based often culturally inherited and important to pharmacology and local livelihood this means as their answer traditional therapies are currently being eroded due to changing life styles, awareness, social transformation and acculturation

\section{Discussion}

This study recorded the use of 30 plant species which to treat for different ailments. On this study I have discussed about a few medicinal plants which growth in Haramaya cultivated wild used to treat from ailments (diseases), the population of that environments are as their social transpiration and a cultural tradition.

Medicinal plant part used for ethno medicinal preparation were seed, fruit, flowers, leaf, root, stem and the whole parts of plants. The most frequently utilized plant parts in this study were roots, seeds, leaves, stems, and leaves bud, jelly of the stem and fruits.

From the data about 8 species of plants followed to treat ailments are seeds. Followed by leaves 10 species, roots of 2 species, stems of 3 species and the other lefts are by terminal bud, leaves, and root, leaves bud, jelly of the stem, seeds and fruit for remedies.

Preparation methods for therapies included decoction, drying, extraction. Plant infusion (smoke), juice, latex, oil, paste, powder, raw (fresh) and resin were also applied. These are the most popular forms of medicinal traditional remedies were prepared as via boiling, pounding, burning, macerating, crushing, steaming and raw prescription, frying and squeezing were also employed and prescribed orally.

\section{Conclusion and Recommendation}

This research was under taken with understanding that the use of safe effective medicinal traditional plant species can reduce farmers in put cost, preserve the resource base, enhance the bio diversity and protect human health. 
Medicinal plants are in separable from local livelihoods, because they have long been collected consumed and managed through local customs and knowledge.

Generally, this study recorded the use of 30 plant species, parts of plants used and methods of preparation for human being health care system. The demand for indigenous medicines and services is considerable relative the health care services. The poor population inHaramaya indicated that they relied on the health care system and indigenous medicine.

From this study it can be suggested that because traditional method of treating diseases are very adopted by the people and important to the people the government should encourage the healers by creating awareness to the modern remedies. The traditional way of transferring the knowledge of traditional medicines should document.

\section{References}

[1] Pankhurst, R. (1990). An introduction to the medical history of Ethiopia. New Jersey, USA: TheRed Sea Press, Inc.

[2] Bishaw, M. (1991). Promoting traditional medicine in Ethiopia: a brief historical review of government policy. Social Science and Medicine, 33, 193-200.

[3] Kassaye, K. D., Amberbir, A., Getachew, B., Mussema, Y. (2006). A historical overview of traditional medicine practices and policy in Ethiopia. Ethiopian Journal of Health Development, 20, 127-134.

[4] Papadopoulos, R., Lay, M., Gebrehiwot, A. (2002 May). Cultural snapshots: A guide to Ethiopian refugees for health care workers. Research Center for Trans-cultural Studies in Health.Middlesex University, London. Available on-line: http://www.mdx.ac.uk/www/rctsh/embrace.htm.

[5] Lietava, J., 1992. Medicinal plants in a middle Palaeolithic grave Shanidar IV? Journal ofEthnopharmacology 35, 263 266.

[6] Balick, M., Cox, P., 1996. Plants, People and Culture. The Science of Ethnobotany. Scientific American Library, USA, $228 \mathrm{pp}$.

[7] Chadwick, D. J., Marsh, J. (Eds.), 1994. Ethnobotany and the search for new drugs. In: Ciba Foundation Symposium, vol. 185. Wiley, Chichester, $280 \mathrm{pp}$.

[8] Karan Vasisht and Vishavjit Kumar (2004) Medicinal and Aromatic Plants Padriciano 99, 34012 Trieste, Italy.

[9] MesfinTadesse and SebsebeDemissew, 1992. Medicinal Plants Ethiopian: Inventory, Identification and Classification. In: Sue Edwards \&ZemedeAsfaw, (eds.). Plants Used in African Traditional Medicine as Practiced in Ethiopia and Uganda. Botany 2000: East and Central Africa. NAPRECA Monograph Series No. 5: 1-24.

[10] Jansen, P. C. M. 1981. Spices, Condiments and Medicinal plants in Ethiopia: Their Taxonomic and agricultural significance. Centre for agricultural publishing and documentation. Wageningen, the Netherlands.
[11] Pankhurst, R. 2001. The status and availability of oral and written knowledge on traditional health care. In: Conservation and Sustainable Use of Medicinal Plants in Ethiopia Proceeding of The National Workshop on Biodiversity Conservation and Sustainable Use of Medicinal Plants in Ethiopia, 28 April-01 May 1998, pp.92-106 (MedhinZewdu and AbebeDemissie eds.). IBCR, AA.

[12] Dawit, A. 1986. Traditional medicine in Ethiopia. The attempt being made to promote it for effective and better utilization. SINET: Ethiopian Journal of Scince 9, 61-69. Addis Ababa, Ethiopia.

[13] Debela, H. 2001. Use and Management of Traditional Medicinal Plants by Indigenous People of Boosat Woreda, Wolenchiti Area: AnEthnobotanical Aproach. M.Sc. Thesis, Addis Ababa University.

[14] Ankobonggo, W. 1992. The Role of African Traditional Medicine in Healthcare Delivery alongside Modern Medicine. In: Plants used in African traditional medicine as practiced inEthiopia and Uganda. Botany 2000. East and Central Africa. NAPRECA MonographSeries. 2: 25-35. (Edwards, S. and ZemedeAsfaweds.). Published by NAPRECA, Addis Ababa University, Addis Ababa.

[15] Mirgissa Kaba (1998). Utilization of plant medicine for the treatment of health problems. The case of Oromo of Chora Wereda Illubabor Zone, Western Ethiopia. The EthiopianJournalof Health Development, 10(3): 161-166.

[16] Mirutse Giday (1999). An Ethnobotanicalstudy of medicinal plants used by the Zay People in Ethiopia. M.Sc. Thesis. Uppsala, Sweden.

[17] Endalew Amenu (2007). Use and Management of Medicinal Plants by indigenous People ofEjaji Area (Chelya Wereda) West Shewa, Ethiopia: An Ethnobotanical Approach. M.Sc. Thesis. Addis Ababa, Ethiopia.

[18] Etana Tolasa (2007). Use and Conservation of Traditional Medicinal Plants by Indigenous People in Gimbi Wereda, Western Wellega. M.Sc. Thesis. Addis Ababa, Ethiopia.

[19] Fisseha Mesfin (2007). An Ethnobotanical Study of medicinal Plants in Wonago Wereda, SNNPR, Ethiopia. M.Sc. Thesis. Addis Ababa, Ethiopia.

[20] Haile Yineger and Delenasaw Yewhalaw (2007). Traditional medicinal plant knowledge and use bylocal healers in Sekoru Wereda, Jimma Zone, southwestern Ethiopia. Journal of Ethnobiology Ethnomedicine, 3: 24.

[21] Tilahun Teklehaymanotand Mirutse Giday (2007). Ethnobotanical study of medicinal plants used by people in Zegie Peninsula, Northwestern Ethiopia. Journal of Ethnobiology and Ethnomedicine.3: 12.

[22] Ermias Lulekal, Ensermu Kelbessa, Tamrat Bekele, and Haile Yineger.(2008). An ethnobotanical study of medicinal plants in Mana Angetu Wereda, southeastern Ethiopia. Journal of Ethnobiology Ethnomedicine4: 10.

[23] Zewdie Kassa (2009). An Ethnobotanical Study of MedicinalPlants and Biodiversity of Trees and Shrubs in Jeldu Wereda, Western Shewa, Ethiopia. M.Sc. Thesis. Addis Ababa, Ethiopia. 